\title{
KESADARAN SEJARAH DAN PARTISIPASI MASYARAKAT DALAM PELESTARIAN MONUMEN JENDERAL SOEDIRMAN (STUDI KASUS DI DESA PAKIS BARU KECAMATAN NAWANGAN KABUPATEN PACITAN)
}

\author{
Abraham Nurcahyo \\ Nur Hidayati *)
}

\begin{abstract}
Abstrak
Penelitian ini bertujuan untuk mengetahui sejauh mana kesadaran dan partisipasi masyarakat terhadap pelestarian monumen Jenderal Soedirman. Penelitian ini dilakukan di Desa Pakis Baru Kecamatan Nawangan Kabupaten Pacitan selama enam bulan. Data diperoleh dari sumber primer dan sumber skunder. Teknik pengambilan data dengan wawancara, observasi dan dokumentasi. Analisis data menggunakan analisis kualitatif model interaktif. Objek penelitian adalah masyarakat Desa Pakis Baru dengan mengambil sampel aparat pemerintah, penjaga monumen, masyarakat sekitar monumen.

Hasil penelitian menunjukkan bahwa kesadaran masyarakat Desa Pakis Baru dalam melestarikan monumen Jenderal Soedirman masih sangat rendah. Hal ini disebabkan karena kurangnya kesadaran masyarakat tentang arti pentingnya peninggalan sejarah, masyarakat yang bersifat materialistik, masyarakat yang cenderung menunggu perintah aparat desa, kurangnya sosialisasi tentang pentingnya peninggalan sejarah.
\end{abstract}

Kata Kunci: Kesadaran sejarah, Partisipasi, Pelestarian

\section{Pendahuluan}

Peristiwa masa lalu memberikan arti tersendiri bagi kehidupan manusia, salah satunya yaitu sejarah perjuangan bangsa Indonesia. Para pahlawan berjuang sampai titik darah penghabisan, mereka rela mengorbankan segalanya demi satu tujuan yaitu negara merdeka. Oleh sebab itu bangsa yang besar adalah bangsa yang menghargai jasa pahlawannya. Melalui pendidikan sejarah manusia akan memperoleh informasi tentang perjuangan pahlawan yang telah gugur dalam memperjuangkan kemerdekaan Indonesia.

\footnotetext{
* Abraham Nurcahyo adalah Dosen Pendidikan Sejarah IKIP PGRI MADIUN Nur Hidayati adalah Mahasiswa Pendidikan IKIP PGRI MADIUN
}

21|Agastya Vol. 02 No. 01 . Januari 2012 
Pendidikan sejarah mengajarkan pada kita tentang perbuatan manusia di masa lampau. Dari perbuatan-perbuatan manusia tersebut kita dapat bercermin dan menilai perbuatan mana yang merupakan "keberhasilan" dan mana yang merupakan "kegagalan". Dengan demikian kita dapat lebih berhati-hati agar kegagalan itu tidak terjadi lagi (Rustam E. Tamburaka, 1999:43-44).

Maka penting bagi suatu bangsa untuk memperdalam dan mempertegas pengertian sejarahnya yang dapat menyinari dan menghayati kepribadian nasional. Maka kita harus sadar dan waspada agar kepribadian nasional tidak dilepaskan dari jangkar kesadaran sejarah. Kesadaran sejarah merupakan suatu orientasi intelektual, suatu sikap jiwa yang perlu untuk memahami secara tepat paham kepribadian nasional. Kesadaran sejarah membimbing manusia mengenai diri sendiri sebagai bangsa, kepada self understanding of a nation, kepada sangkan paran suatu bangsa, kepada persoalan what we are, why we are. Kita juga memerlukan kesadaran sejarah supaya kita peka terhadap dimensi waktu didalam proses perwujudan suatu masyarakat dan kebudayaan baru (Soejatmoko, 1986:66-68).

Budhisantoso (dalam Depdikbud, 1986:21-22) menjelaskan bahwa kesadaran sejarah penting dalam pembinaan budaya bangsa karena memerlukan dukungan dan peran serta secara aktif segenap anggota masyarakat. Untuk menggerakkan peran serta masyarakat dalam membina dan memperkembangkan kebudayaan nasional perlu dibangkitkan kesadaran bahwa mereka merupakan suatu kesatuan sosial yang terwujud melalui proses sejarah yang akhirnya mempersatukan sejumlah nasion kecil dalam suatu nasion Indonesia. Kesadaran sejarah sebagai satu bangsa dapat berfungsi sebagai pengikat dan pengarah perkembangan kebudayaan nasional Indonesia yang tidak hanya bertumpu pada apa yang telah diwariskan oleh nenek moyang bangsa Indonesia, melainkan juga menyesuaikan diri dengan perkembangan masyarakat dan pembaharuan lingkungan.

Dengan semakin tinggi kesadaran masyarakat maka semakin tinggi partisipasinya khususnya dalam pembangunan untuk mencapai tujuannya. Peningkatan kesadaran masyarakat tidak sekedar menanamkan pengertian masyarakat terhadap permasalahannya saja, tetapi membangkitkan partisipasi untuk ikut memelihara kelestariannya, yang diperlukan adalah masyarakat yang aktif mengawasi dan menjaga secara langsung (Moh. Soerjani dkk, 1987:270).

Di Kabupaten Pacitan banyak peninggalan-peninggalan sejarah. Salah satunya adalah monumen Jenderal Soedirman. Jenderal Soedirman adalah seorang pahlawan yang melawan penjajah, dimana dalam melawan penjajah beliau menggunakan taktik gerilya sehingga beliau selalu berpindah-pindah dari satu tempat ke tempat yang lain. Dalam perjalanan perangnya beliau selalu ditandu karena beliau dalam keadaan sakit. Jenderal Soedirman menjalankan taktik perang gerilyanya berangkat dari Jogjakarta dan akhirnya beliau sampai di daerah Sobo yang terletak di Desa Pakis Baru Kecamatan Nawangan Kabupaten Pacitan.

Untuk mengenang jasa Jenderal Soedirman maka dibangunlah sebuah monumen di daerah tersebut. Monumen Jenderal Soedirman ini dibangun diperbukitan dengan medan yang cukup sulit. Patung Jenderal Soedirman ini berdiri kokoh dengan mengenakan jas panjang, berbelangkon dengan tangan kiri memegang tongkat kayu dan menghadap ke utara. Selain patung dikompleks ini terdapat lapangan pendaratan helikopter, ruang 
pertemuan, perpustakaan, tempat parkir dan instalasi pengolahan air. Monumen Jenderal Soedirman ini ramai dikunjungi wisatawan terutama pada hari libur, pada hari-hari biasa tidak terlalu ramai dikunjungi wisatawan.

Masyarakat Desa Pakis Baru yang mayoritas bermata pencaharian sebagai petani merasa beruntung dengan dibangunnya monumen tersebut sebagai tempat pariwisata sehingga hal ini dapat dimanfaatkan untuk menambah pendapatan mereka yaitu dengan berdagang di sekitar area monumen tersebut. Selain itu mereka juga menyadari monumen Jenderal Soedirman ini sangat penting sebagai peninggalan sejarah yang perlu dirawat dan dilestarikan.

Sejalan dengan perkembangannya pada saat ini maka menarik untuk diadakan penelitian tentang bagaimana kesadaran sejarah dan partisipasi masyarakat terhadap pelestarian monumen Jenderal Soedirman di Desa Pakis Baru Kecamatan Nawangan Kabupaten Pacitan tahun 1998-2011.

\section{Tujuan dan Manfaat Penelitian}

Tujuan penelitian ini adalah untuk mengetahui bagaimana kesadaran sejarah dan partisipasi masyarakat terhadap pelestarian monumen Jenderal Soedirman di Desa Pakis Baru Kecamatan Nawangan Kabupaten Pacitan tahun 1998-2011. Hasil panelitian ini diyakini dapat bermanfaat bagi beberapa pihak yaitu:

\section{Bagi Guru Sejarah}

Bagi guru sejarah hasil penelitian ini sangat bermanfaat karena dapat memberikan pendidikan pada anak didik untuk menghargai nilai-nilai perjuangan dan menghargai monumen sebagai wujud untuk mengenang jasa pahlawan dan dapat dijadikan sebagai media bagi pembelajaran khususnya sejarah.

\section{Bagi Masyarakat}

Bagi masyarakat penelitian ini berguna untuk memberikan wawasan kesejarahan kepada masyarakat supaya lebih paham dan terbuka wawasan terhadap pelestarian peninggalan-peninggalan sejarah.

\section{Bagi IKIP PGRI Madiun}

Bagi IKIP PGRI Madiun penelitian ini dapat berguna sebagai literatur perpustakaan, dan sebagai bahan kajian untuk penelitian lebih lanjut.

\section{Tinjauan Pustaka}

\section{Kesadaran Sejarah}

Sebagai warga negara Indonesia dan sebagai manusia semestinya terlibat dan ikut bertanggung jawab dalam penulisan sejarah bangsanya, karena suatu bangsa menghadapkan diri dengan kenyataan, dengan realitas sosial dalam perspektif hari kini, hari lampau dan perspektif hari depan. Penting bagi suatu bangsa untuk memperdalam dan mempertegas pengertian sejarahnya yang dapat menyinari dan menghayati kepribadian nasional. Refleksi diri yang kontinyu berdasarkan kesadaran sejarah akan membebaskan manusia Indonesia dari rasa diri yang serba metologis. Kesadaran sejarah merupakan orientasi intelektual, suatu sikap jiwa yang perlu untuk memahami secara tepat paham kepribadian nasional (Soedjatmoko, 1986:66-67).

Kesadaran sejarah adalah kesadaran yang menunjukkan satu tingkat penghayatan pada makna serta hakikat sejarah (dinamika sejarah) sebagai tuntunan menghadapi masa kini dan masa yang akan datang. Untuk bisa melangkah sampai pada 
pemaknaan sejarah yang benar diperlukan dua prakondisi (kondisi objektif) yang perlu dikembangkan.

Pertama, perlu ada upaya terus menerus menjernihkan sejarah atau meluruskan kecenderungan ke arah "pemitosan" sejarah yang biasanya menyebabkan realitas sejarah digiring kearah pembenaran kepentingan pribadi atau kelompok, dalam kondisi yang seperti ini sulit menciptakan situasi yang kondusif untuk mendorong proses belajar dari sejarah (pemaknaan sejarah) yang benar. Kedua adalah oleh karena setiap generasi menghadapi semangat atau tuntutan jaman yang berbeda, maka proses pemaknaan sejarah bagi generasi baru sering disebut "pewarisan nilai sejarah" memerlukan dialog antar generasi artinya pewarisan nilai tidak bisa berjalan satu arah atau dipaksakan, tetapi memerlukan interaksi dua arah (Gde Widja, 2002:10-11).

Pentingnya manusia mengetahui sejarah (kesadaran sejarah) yaitu sejarah mengajarkan tentang perbuatan manusia di masa lampau. Dari perbuatan-perbuatan manusia tersebut, dapat bercermin dan menilai perbuatan mana yang merupakan "keberhasilan" dan mana yang merupakan "kegagalan", dengan demikian kita lebih dapat berhati-hati agar kegagalan itu tidak terulang kembali. Dengan mengetahui sejarah, kita akan selalu waspada terhadap berbagai dampak negatif perubahan dan globalisasi (Rustan E. Tamburaka, 1999:4344).

Salah satu sikap terhadap sejarah setelah orang mengetahui masa lampaunya yaitu dengan berpartisipasi dalam melestarikan peninggalan sejarah dan merasa bertanggung jawab dalam pemeliharaannya sebab peninggalan sejarah merupakan sumber sejarah yang sangat bermakna.

\section{Partisipasi}

Britha Mikkelsen (terjemah Matheos Nalle, 2003:64) menjelaskan partisipasi merupakan kata yang sangat sering digunakan dalam pembangunan. Istilah partisipasi mempunyai banyak ragam arti yaitu:

a. Partisipasi adalah konstribusi sukarela dari masyarakat kepada proyek tanpa ikut serta dalam pengambilan keputusan;

b. Partisipasi adalah "pemekaan" (membuat peka) pihak masyarakat untuk meningkatkan kemauan menerima dan kemampuan untuk menanggapi proyekproyek pembangunan;

c. Partisipasi adalah suatu proses yang aktif, yang mengandung arti bahwa orang atau kelompok yang terkait, mengambil inisiatif dan menggunakan kebebasannya untuk melakukan hal itu;

d. Partisipasi adalah pemantapan dialog antara masyarakat setempat dengan para staf yang melakukan persiapan, pelaksanaan, monitoring proyek, supaya memperoleh informasi mengenai konteks lokal, dan dampak-dampak sosial;

e. Partisipasi adalah keterlibatan sukarela oleh masyarakat dalam perubahan yang ditentukan sendiri; dan

f. Partisipasi adalah keterlibatan masyarakat dalam pembangunan diri, kehidupan, dan lingkungan mereka.

Semakin tinggi kesadaran masyarakat maka semakin tinggi pula partisipasinya khususnya dalam pembangunan untuk mencapai tujuannya. Peningkatan kesadaran masyarakat tidak sekedar menanamkan pengertian masyarakat terhadap permasalahannya saja, tetapi membangkitkan partisipasi untuk ikut memelihara kelestariannya, sehingga diperlukan masyarakat yang aktif mengawasi dan menjaga secara langsung (Moh. Soerjani dkk, 1987:270). 
Timbulnya kesadaran akan masa lampaunya tersebut maka akan timbul keinginan untuk berpartisipasi secara aktif untuk mendukung kelancaran dalam mencapai tujuan bersama. Sehingga masyarakat yang sadar akan selalu menjaga dan merasa bertanggung jawab terhadap pelestarikan peninggalan masa lampau tersebut. Semakin tinggi perhatian seseorang terhadap peninggalan sejarah (monumen) maka akan semakin tinggi partisipasinya dalam menjaga kelestariannya, sebab partisipasi masyarakat merupakan kunci utama bagi kelestarian peninggalan sejarah.

\section{Metode Penelitian}

\section{Tempat dan Waktu Penelitian}

Penelitian ini dilakukan di Desa Pakis

Baru Kecamatan Nawangan Kabupaten Pacitan. Dipilihnya tempat ini sebagai tempat penelitian karena di desa ini terdapat peninggalan yang sangat berharga dan mempunyai nilai historis yang sangat tinggi. Sedangkan waktu penelitian yang digunakan 6 bulan (Februari-Juli 2011).

2. Sumber Data Penelitian

Sumber data yang digunakan dalam penelitian ini berasal dari sumber Data Primer yaitu data yang diperoleh melalui sumber pertama yaitu berupa hasil wawancara dan hasil diskusi, yang kedua diperoleh dari sumber data skunder yaitu data yang diperoleh melalui sumber kedua berupa dokumen-dokumen tertulis, bukubuku teks dan berbagai sumber lain yang mendukung.

\section{Pengambilan Data}

Pengambilan data penelitian menggunakan teknik wawancara, observasi, dan dokumentasi.

\section{Analisis Data}

Analisis data yang digunakan adalah analisis kualitatif model interaktif (Miles dan
Huberman 1994) sebagaimana bagan di bawah ini:

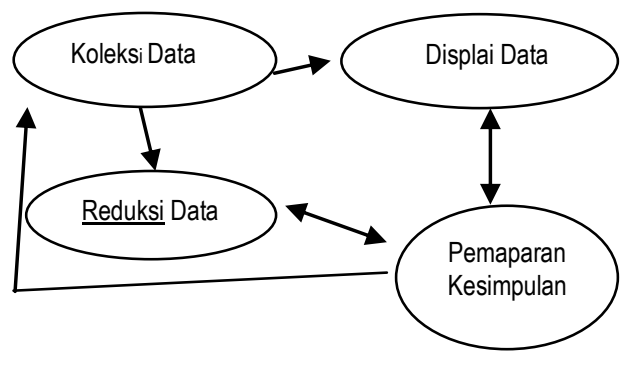

Bagan 1 Analisis data model interaktif

\section{Hasil Penelitian}

\section{A. Gambaran Umum Desa Pakis Baru}

\section{Letak Desa}

Desa Pakis Baru terletak di wilayah Kecamatan Nawangan Kabupaten Pacitan. Jarak Desa Pakis Baru dengan Kabupaten Pacitan kurang lebih $32 \mathrm{~km}$. Secara adminitratif batas Desa Pakis Baru meliputi sebelah utara dibatasi oleh Desa Brenggolo, sebelah selatan dibatasi oleh Desa Jetislor, sebelah timur dibatasi oleh Desa Ngromo, sebelah barat dibatasi oleh Desa Penggung. Wilayah Desa Pakis Baru merupakan dataran tinggi dengan luas 1.151,47 ha berupa lahan pemukiman, lahan persawahan, lahan perkebunan, lahan kuburan, lahan pekarangan, lahan taman, lahan perkantoran, lahan untuk prasarana umum lainnya. Desa Pakis Baru merupakan gabungan dari 5 (lima) pedukuhan yaitu: Dukuh Krajan, Dukuh Tempel, Dukuh Menur, Dukuh Katosan, Dukuh Ngromo (monografi Desa Pakis Baru tahun 2010).

\section{Demografi Desa Pakis Baru}

a. Penduduk

Berikut ini pembagian jumlah penduduk Desa Pakis Baru menurut: 
1) Jumlah penduduk berdasarkan jenis kelamin

Jumlah penduduk Desa Pakis Baru secara keseluruhan berjumlah 5222 orang, dimana penduduk laki-laki 2574 orang dan penduduk perempuan berjumlah 2648 orang.

a) Tingkat Usia

Pembagian jumlah penduduk berdasarkan tingkat usia adalah sebagai berikut:

\begin{tabular}{|c|c|c|c|}
\hline No & Usia & Jumlah & Prosentase \\
\hline 1 & $\begin{array}{c}0-12 \\
\text { bulan }\end{array}$ & 30 orang & $0,57 \%$ \\
\hline 2 & $\begin{array}{c}1-5 \\
\text { tahun }\end{array}$ & 276 orang & $5,29 \%$ \\
\hline 3 & $\begin{array}{c}7-18 \\
\text { tahun }\end{array}$ & 809 orang & $15,50 \%$ \\
\hline 4 & $\begin{array}{c}18- \\
56 \\
\end{array}$ & 2.466 orang & $47,22 \%$ \\
tahun & & \\
\hline 5 & $\begin{array}{c}>56 \\
\text { tahun }\end{array}$ & 1.332 orang & $25,50 \%$ \\
\hline
\end{tabular}

Sumber: monografi Desa Pakis Baru 2010

Berdasarkan tabel 4.1 diatas dapat diketahui bahwa sebagian besar penduduk Desa Pakis Baru yaitu 51,01\% (2664 jiwa) berusia antara 18-56 tahun.

b). Mata Pencaharian

Pembagian jumlah penduduk berdasarkan mata pencaharian adalah sebagai berikut:

Tabel 2 Distribusi penduduk berdasarkan mata pencaharian :

\begin{tabular}{|r|l|r|}
\hline No & \multicolumn{1}{|c|}{$\begin{array}{c}\text { Tingkat } \\
\text { Pendidikan }\end{array}$} & Jumlah \\
\hline 1 & Tamat SD & 1.557 orang \\
\hline 2 & Tamat SLTP & 1.118 orang \\
\hline 3 & Tamat SLTA & 296 orang \\
\hline 4 & Tamat D-1 & 6 orang \\
\hline
\end{tabular}

\begin{tabular}{|c|l|r|}
\hline 5 & Tamat D-2 & 7 orang \\
\hline 6 & Tamat D-3 & orang \\
\hline 7 & Tamat S1 & 66 orang \\
\hline 8 & $\begin{array}{l}\text { Tidak tamat } \\
\text { sekolah }\end{array}$ & 97 orang \\
\hline
\end{tabular}

Sumber: Monografi Desa Pakis Baru tahun 2010

Berdasarkan tabel 4.3 diatas dapat diketahui bahwa sebagian besar penduduk Desa Pakis Baru yaitu tamatan Sekolah Dasar (SD) yaitu sebanyak 1.557 orang.

2). Agama

Pembagian jumlah penduduk berdasarkan agamanya adalah sebagai berikut:

Tabel 4 Jumlah Penduduk Berdasarkan Agama

\begin{tabular}{|c|l|r|}
\hline No & \multicolumn{1}{|c|}{ Agama } & \multicolumn{2}{c|}{ Jumlah } \\
\hline 1 & Islam & 5.222 orang \\
\hline 2 & Kristen & - orang \\
\hline 3 & Katolik & - orang \\
\hline 4 & Hindu & - orang \\
\hline 5 & Budha & - orang \\
\hline 6 & Konghucu & - orang \\
\hline 7 & $\begin{array}{l}\text { Aliran } \\
\text { Kepercayaan } \\
\text { lain }\end{array}$ & - orang \\
\hline
\end{tabular}

Sumber : Monografi Desa Pakis Baru tahun 2010.

\section{B. Proses Pembangunan Monumen Jenderal Soedirman}

\section{Latar Belakang Pembangunan Monumen}

Monumen Jenderal Soedirman dibangun oleh lurah Desa Pakis yang bernama Roto Soewarno, beliau adalah salah seorang kurir Jenderal Soedirman pada waktu tinggal di Dukuh Sobo. Monumen Jenderal Soedirman dibangun sebagai sarana untuk mengenang jasa-jasa Jenderal Seodirman sebagai pahlawan bangsa yang pada saat pejuangannya beliau tinggal di Dukuh Sobo yang terletak di Desa Pakis Baru. Monumen Jenderal Soedirman 
dibangun di atas bukit yaitu di gunung Gandrung, yang dahulu di tempat tersebut Jenderal Soedirman beserta rombongannya pernah berhenti untuk mengganti tali temali tandu Jenderal Soedirman dan pergantian yang memikul tandu Jenderal Soedirman. Monumen Jenderal Soedirman dibangun mulai tanggal 29 Januari 1981 yang bertepatan dengan memperingati hari wafatnya Jenderal Soedirman.

Dalam pembangunan tersebut banyak mengalami kendala sehingga pembangunannya tersendat-sendat hingga tahun 1992 baru selesai $60 \%$. Luas area bangunan Monumen Jenderal Soedirman tersebut adalah 10 ha. Setelah pak Roto Soewarno meninggal yaitu pada tanggal 27 Juni 1993 pembangunan monumen Jenderal Soedirman tersebut terhenti, sehingga mulai tahun 1993 sampai tahun 1998 keadaan monumen Jenderal Soedirman terbengkalai.

Pada tahun 1998 di Desa Pakis Baru ada sosialisasi Pilgub Jawa Timur yang pada saat itu juga di hadiri oleh Andi Malarangeng dan Edi Baskoro dan juga di ikuti oleh Bupati Pacitan Suyono. Pada saat itu juga pemerintah Desa Pakis Baru mengajukan proposal kepada pemerintah pusat untuk melanjutkan pembangunan monumen Jenderal Soedirman. Pengajuan proposal tersebut disetujui oleh presiden Susilo Bambang Yudhoyono, pembangunan monumen tersebut dilanjutkan dan diharapkan dapat selesai dalam jangka waktu 3 bulan, setelah selesai pada tanggal 15 Desember 2008 presiden Susilo Bambang Yudhoyono berkunjung ke monumen Jendral Soedirman guna peresmian monumen tersebut (wawancara dengan Joko Mulyono, tanggal 11 April 2011).

\section{Wujud Fisik Bangunan}

Patung Jenderal Soedirman dibangun diatas bukit di Dukuh Sobo yaitu di gunung Gandrung. Patung Jendral
Soedirman ini berdiri kokoh setinggi 8 meter dengan berat 8 ton dan terbuat dari peruggu. Patung Jenderal Soedirman ini dibuat menghadap ke utara dengan memakai jas panjang, berblangkon dengan tangan kirinya menggenggam tongkat kayu. Selain itu juga terdapat jalan menuju monumen yang berwujud berundak-undak (pelataran) yang terdiri dari tiga tingkatan, pada tingkatan pertama berjumlah 17, kedua 8 dan ketiga bejumlah 45 yang mengandung makna hari kemerdekaan bangsa Indonesia. $\mathrm{Di}$ depannya juga terbentang lapangan luas yang berukuran $8 \times 100$ meter dan memiliki tembok serta gapura (wawancara dengan Sukatno, tanggal 21 April 2011).

Sarana dan prasarana yang terdapat di monumen Jenderal Soedirman ini diantaranya yaitu lapangan pendaratan helikopter, diorama, ruang resepsionis, perpustakaan, restoran, gedung teater, pasar seni, kamar mandi umum wawancara dengan Sidik, tanggal 21 April 2011).

Di samping itu juga terdapat relief yang berjumlah 38 buah yang menceritakan kehidupan Jenderal Soedirman sejak beliau lahir sampai meninggal. Adapun reliaef yang ada di monumen Jenderal Soedirman ini diuraikan sebagai berikut: 1) Rumah tempat kelahiran Jenderal Soedirman, 2) Belajar mengaji Sekolah Pramawiwonotomo, 3) Latihan Kepanduan, 3) Menjadi guru dan menikah 4) Mendirikan koperasi, 5) Mengikuti tentara PETA, 6) Menjadi Daidancho di Kroya, 7) Memimpin pertempuran Ambarawa, Peta pertempuran Ambarawa, Konverensi tentara keamanan rakyat, Menjadi panglima besar, Mengucapkan sumpah sebagai panglima besar, Shalat Idul Adha, Perundingan Linggajati, Agresi militer Belanda I, Perjanjian Renville, TNI hijrah, Serangan terhadap ibu kota RI, Memutuskan bergerilya, Perintah kilat, Berangkat bergerilya, Pengorbanan bu Soedirman, Memimpin gerilya, Memimpin 
gerilya naik dokar, Memimpin gerilya di atas tandu, Peristiwa Gunung Wilis, Menyamar sebagai penduduk setempat,Markas besar komando gerilya di Sobo Pacitan,Serangan umum 1 Maret 1949 di Yogyakarta, Komunikasi dengan ketua pemerintah darurat Republik Indonesia, Penarikan tentara Belanda, Menerima laporan Letkol Soeharto, Kembali ke Yogyakarta, Pertemuan dengan Presiden dan Wakil Presiden, Menerima parade kehormatan, Dirawat di rumah sakit panti rapih , Panglima besar Soedirman wafat

Bangunan Monumen Jenderal Soedirman juga mempunyai nilai-nilai simbolik diantaranya yaitu:

a. Bangunan gate yang berjumlah 8 mempunyai arti bahwa pada saat indonesia merdeka baru terdiri dari 8 propinsi. Pada setiap gate tersebut bertuliskan pesanpesan Jenderal Soedirman kepada pasukannya diantaranya bertuliskan: 1) kemerdekaan sudah digenggam jangan dilepaskan!, 2) keteguhan hati adalah modal utama terus berjuang, 3) Tentara Republik Indonesia akan timbul tenggelam bersama waktu, 4) Tentara Republik indonesia bukanlah serdadu sewaan tetapi tentara yang berjuang untuk keluhuran tanah air, 5) Bersatu!, berjuang bersama!, Jangan bertengkar!, 6) walau dengan satu paru-paru dan ditandu pantang menyerah, 7) bahwa satu-satunya hak milik nasional republik yang masih tetap utuh tidak berubah-ubah meskipun harus menghadapi segala macam soal dan perubahan adalah angkatan perang Republik Indonesia ( Tentara Nasional Indonesia).

b. Pedangpora yang dibangun tepat di pintu masuk monumen yang berjumlah 12 dibangun dalam bentuk agak menunduk, hal ini dimaksudkan sebagai bentuk penghormatan TNI terhadap Jenderal Soedirman.

c. Pelataran yang berjumlah $17,8,45$ mempunyai maksud hari kemerdekaan
Indonesia ( wawancara dengan Sidik, tanggal 11 Mei 2011).

\section{Riwayat Hidup Jenderal Soedirman}

Jenderal Besar TNI Anumerta Soedirman lahir di Bodas Karangjati, Purbalingga, Jawa Tengah pada tanggal 24 Januari 1916. Dalam sejarah perjuangan Republik Indonesia, ia dicatat sebagai Panglima dan Jenderal RI yang pertama dan termuda. Saat usia 31 tahun ia telah menjadi seorang jenderal. Meski menderita sakit tuberkulosis paru-paru yang parah, ia tetap bergerilnya dalam perang pembelaan kemerdekaan RI. Jenderal Soedirman dibesarkan dalam lingkungan keluarga sederhana. Ayahnya bernama Karsid Kartowirodji adalah seorang pekerja di pabrik gula Kalibagor, Banyumas dan ibunya Siyem adalah keturunan Wedana Rembang.

Soedirman memperoleh pendidikan formal dari Sekolah Taman Siswa, kemudian beliau melanjutkan ke HIK (Sekolah Guru) Muhammadiyah Surakarta, tetapi tidak sampai tamat. Soedirman saat itu juga giat di organisasi Pramuka Hizbul Wathan. Setelah itu ia menjadi guru di sekolah HIS Muhammadiyah di Cilacap.

Ketika jaman pendudukan Jepang, beliau masuk tentara Pembela Tanah Air (PETA), ia menjadi Komandan Batalyon di Kroya, Jawa Tengah. Kemudian ia menjadi Panglima Divisi V Banyumas sesudah TKR terbentuk dan akhirnya terpilih menjadi Panglima Angkatan Perang Republik Indonesia.

Soedirman dikenal dengan pribadinya yang teguh pada prinsip dan keyakinan, selalu mengedepankan kepentingan masyarakat banyak dan bangsa di atas kepentingan pribadinya. Pada masa pendudukan Jepang ini, Soedirman pernah menjadi anggota Badan Pengurus Makanan Rakyat dan anggota Dewan Perwakilan Rakyat Karesidenan Banyumas. Dalam hal 
ini beliau mendirikan koperasi untuk menolong rakyat dari bahaya kelaparan.

Setelah berakhirnya Perang Dunia II, pasukan Jepang menyerah tanpa syarat kepada pasukan sekutu dan Soekarno mendeklarasikan kemerdekaan Indonesia. Soedirman mendapat prestasi pertamanya sebagai tentara setelah keberhasilannya merebut senjata pasukan Jepang dalam pertempuran di Banyumas, Jawa Tengah. Sesudah Tentara Keamanan Rakyat (TKR) terbentuk, beliau kemudian diangkat menjadi Panglima Divisi $V$ Banyumas dengan pangkat Kolonel. Melalui Konferensi TKR tanggal 12 November 1945, Soedirman terpilih menjadi Panglima Besar TKR.

Menangnya pasukan Sekutu atas Jepang dalam Perang Dunia II membawa pasukan Belanda datang kembali ke kepulauan Hindia Belanda dengan alasan untuk melucuti tentara Jepang. Ternyata pasukan Sekutu datang bersama dengan tentara NICA dari Belanda yang hendak mengambil kembali Indonesia sebagai koloninya. Mengetahui hal tersebut, TKR pun terlibat dalam banyak pertempuran dengan tentara sekutu.

Perang besar pertama yang dipimpin Soedirman adalah perang Palagan Ambarawa melawan pasukan Inggris dan NICA Belanda yang berlangsung dari bulan November sampai Desember 1945. Pada tanggal 12 Desember 1945, Soedirman melancarkan serangan serentak terhadap semua kedudukan Inggris di Ambarawa. Pertempuran tersebut diakhiri dengan mundurnya pasukan Inggris ke Semarang. Setelah kemenangan Soedirman dalam Palagan Ambarawa, pada tanggal 18 Desember 1945 dia dilantik sebagai Jenderal oleh Presiden Soekarno.

Saat terjadinya Agresi Militer II Belanda, Ibukota Republik Indonesia dipindahkan di Yogyakarta, karena Jakarta sudah diduduki oleh tentara Belanda.
Soedirman memimpin pasukannya untuk membela Yogyakarta dari serangan Belanda II tanggal 19 Desember 1948 tersebut. Dalam perlawanan tersebut, Soedirman sudah dalam keadaan sangat lemah karena penyakit tuberkulosis yang dideritanya sejak lama. Walaupun begitu dia ikut terjun ke medan perang bersama pasukannya dalam keadaan ditandu, memimpin para tentaranya untuk tetap melakukan perlawanan terhadap pasukan Belanda secara gerilya.

Yogyakarta pun dikuasai Belanda. Saat itu, Presiden Soekarno dan Mohammad Hatta dan beberapa anggota kabinet juga ditangkap oleh tentara Belanda. Karena situasi genting tersebut, Soedirman dengan ditandu berangkat bersama pasukannya dan kembali melakukan perang gerilya. Beliau berpindah-pindah dari hutan satu ke hutan lain, dan dari gunung ke gunung dalam keadaan sakit dan lemah dan dalam kondisi hampir tanpa pengobatan dan perawatan medis.

Setelah Belanda menyerahkan kepulauan nusantara sebagai Republik Indonesia Serikat dalam Konferensi Meja Bundar tahun 1949 di Den Haag, Jenderal Soedirman kembali ke Jakarta bersama Presiden Soekarno, dan Wakil Presiden Mohammad Hatta.

Pada tangal 29 Januari 1950, Jenderal Soedirman meninggal dunia di Magelang, Jawa Tengah karena sakit yang dideritanya. Beliau dimakamkan di Taman Makam Pahlawan Kusuma Negara di Semaki, Yogyakarta. Beliau dinobatkan sebagai Pahlawan Pembela Kemerdekaan. Pada tahun 1997 beliau mendapat gelar sebagai Jenderal Besar Anumerta dengan bintang lima (http://id.wikipedia.org/wiki/ Soedirman, diakses 15 Januari 2011).

\section{Pengembaraan Jenderal Soedirman}

Panglima besar Tentara Indonesia Jenderal Soedirman ketika Yogyakarta 
diserbu oleh Belanda beliau kemudian melakukan perjalanan disertai oleh para pembantu dekatnya dengan dikawal pasukan berjumlah kecil pergi kedaerah pegunungan disebelah tenggara Yogyakarta melalui Grogol, Wonogiri, Djetis dan Bendo. Setibanya di Kediri pada tanggal 23 Desember 1948 dimana beliau membicarakan soal situasi militer dengan Kolonel Soengkono, komandan Divisi 1 Jawa Timur. Pada tanggal 25 Desember 1948 rombongan Jenderal Soedirman meninggalkan kota Kediri untuk berpindah ke lereng gunung Wilis. Beberapa jam kemudian Kediri diserang dan diduduki oleh Belanda. Pada hari itu nampaknya, pihak dinas intel Belanda telah mengetahui dimana Jenderal Soedirman berada. Pada tanggal 30 Desember 1948 sebuah rumah di Karangnongko diserang dan ditembaki oleh pesawat-pesawat pemburu Belanda.

Jenderal Soedirman beserta rombongannya meneruskan perjalanannya disebelah barat Gunung Wilis, tetapi intel Belanda juga mencium jejaknya. Pada tanggal 17 dan 18 Januari 1949 pasukan pengawal Jenderal Soedirman didekat Dukuh Sedayu bertempur dengan patroli Belanda yang beroperasi dari Ponorogo. Dukuh Sedayu kemudian digeledah oleh pasukan patroli Belanda dengan memasuki rumah-rumah penduduk untuk mencari Jenderal Soedirman.

Pada saat itu Jenderal Soedirman dan rombongannya bersembunyi di semaksemak dalam hutan rotan. Pada tanggal 21 Januari 1949 hutan tersebut dikepung oleh pasukan patroli Belanda, tetapi pada malam harinya dalam keadaan gelap gulita dapat meloloskan diri dari pengepungan tersebut. Jenderal Soedirman harus dipapah oleh dua orang waktu menghindari pengejaran patroli Belanda karena penyakit paru-paru yang dideritanya menyebabkan keadaan kesehatan Panglima besar Jenderal
Soedirman semakin menurun, sehingga para pembantu dekatnya menghawatirkan beliau tidak dapat bertahan.

Pasukan Belanda di Jawa Tengah berusaha keras untuk dapat menangkap Panglima Besar TNI, bahkan mereka menggunakan tentara payung yang secara kilat diterjunkan disekitar Wonosari. Jenderal Soedirman waktu terjadi peristiwa serangan telah berada di Dukuh Sobo yang letaknya kurang lebih $80 \mathrm{~km}$ dari sebelah timur Wonosari (Tjokropranolo, 1992:289).

Di Dukuh Sobo Jenderal Soedirman tinggal cukup lama yaitu mulai tanggal 3 Februari - 7 Juli 1949. Pada waktu itu Jenderal Soedirman tinggal di rumah kepala desa Tokawi, pada tanggal 29 Maret 1949 datanglah lurah Pakis berusaha untuk menghadap Jenderal Soedirman. Beliau menguraikan maksud kedatangannya untuk mengajukan usul agar Jenderal Soedirman dan rombongannya pindah ke desanya dengan beberapa alasan yaitu: 1) bahwasannya rumah kepala desa Tokawi banyak didatangi tamu, sehingga dianggap tidak aman terhadap keberadaan Jenderal Soedirman, 2) rumah kepala desa Tokawi terletak ditepi jalan besar menghubungkan pasar Nawangan dengan Tirtomoyo yang pada waktu itu sudah di duduki oleh Belanda, 3) di Desa Tokawi medannya tidak mengijinkan apabila sewaktu-waktu terjadi serangan sangat sulit untuk menyelinap. Setelah Kapten Supardjo mendengar alasan-alasan untuk pindah ke Pakis dan calon-calon tempat yang disediakannya, beliau kemudian berjanji akan melaporkan hal itu kepada Jenderal Soedirman.

Keesokan harinya pada tanggal 30 Maret 1949 datanglah beberapa orang utusan ke rumah kepala desa Pakis dengan tujuan untuk melihat tempat-tempat yang diusulkan sebagai tempat tinggal Jenderal Soedirman. Kemudian dipilih salah satu yaitu yang terletak di Dukuh Sobo wilayah 
Desa Pakis Kecamatan Nawangan. Pada tanggal 31 Maret 1949 Jenderal Soedirman dan rombongannya berangkat menuju ke rumah kepala desa Pakis di Dukuh Jepuruh. Perjalanan ke Desa Pakis dari Desa Tokawi diperlukan waktu kurang lebih 3 jam. Setelah bermalam di rumah kepala desa Pakis keesokan harinya pada tanggal 1 April 1949 Jenderal Sodirman beserta rombongannya menuju ke Dukuh Sobo yang berjarak $5 \mathrm{~km}$ dari rumah kepala desa Pakis.

Dengan melewati jalan terobosan gunung Gandrung yang cukup curam tebingnya dan terletak di antara lerenglereng gunung yang harus dituruni. Akhirnya Jenderal Soedirman dan rombongannya sampai di rumah kabayan Karsosemitro di Dukuh Sobo Desa Pakis. Tempat ini kemudian dijadikan sebagai Markas Besar komando Gerilya dan sebagai tempat tinggal Jenderal Soedirman yang paling lama semasa memimpin perang kemerdekaan, sampai beliau berangkat kembali ke Yogyakarta pada tanggal 7 Juli 1949.

Dalam memimpin perang gerilya yang dilakukan dari Dukuh Sobo Jenderal Soedirman benar-benar telah mewujudkan kepemimpinannya sebagai Panglima Besar Angkatan Perang, karena dari tempat itu banyak dikeluarkan perintah-perintah dan diterima laporan-laporan dari para komandan kesatuan dan anggota pusat pemerintahan sipil dan militer. Jenderal Soedirman berada di daerah Sobo tidak hanya sebagai Panglima Angkatan Perang di medan laga, tetapi juga sebagai bapak dan sesepuh rakyat bahkan ada yang menganggapnya sebagai dukun sakti karena terlihat dari banyak persoalan-persoalan masyarakat yang dimintakan petunjuk beliau. Sampai-sampai pada suatu ketika seseorang datang meyembah dihadapan Jenderal Soedirman dan sambil menghibahiba mohon agar anaknya yang baru lahir diberi nama dan air putih yang diberi mantra- mantra kesehatan. Atas permintaan penduduk yang sama sekali tidak ada sangkut pautnya dengan persoalan perang itu Jenderal Soedirman dengan senang hati pula meluruskannya, selain memberi nama jabang bayi yang baru lahir juga memberi kiriman kain untuk popok. Dengan watak yang demikianlah Jenderal Soedirman berada ditengah-tengah rakyat selama berbulan-bulan sampai tugasnya memimpin perang kemerdekaan selesai.

Selama di Dukuh Sobo Desa Pakis Jenderal Soedirman di samping mengirim utusan-utusan juga sering menerima tamu, diantaranya yaitu Menteri Kehakiman Susanto Tirtoprodjo, Menteri Agama K.H. Masykur, di samping itu juga mendapat tamu pemimpin tentara diantaranya adalah Letkol Slamet Riyadi, Kolonel Zulkifli Lubis, Mayor Sunitioso, Mayor Soeharto dan lain-lain. Hubungan dengan Panglima Tentara dan Teritorium Jawa Kolonel Nasution maupun dengan Sultan Hamengku Buwono IX terselenggara dengan lancar. Pada suatu hari kesehatannya Jenderal Soedirman memburuk. Pada saat itu tidak ada dokter yang mendampinginya, akhirnya dicarikan dokter ahli penyakit dalam dari Solo yaitu Dokter Ramli yang dibantu oleh oleh seorang mahasiswa yang bernama Kuswologito.

Setelah tinggal lama di Dukuh Sobo akhirnya Jenderal Soedirman kembali ke Yogyakarta. Dengan rasa haru dan berat, semua rakyat Dukuh Sobo melepas kepergian Jenderal Soedirman. Diawali dengan permintaan sebuah kursi untuk dipergunakan sebagai tandu dan ucapan terima kasih, berangkatlah rombongan Jenderal Soedirman menuruni lembah sungai merang, menjelajahi bukit-bukit Selobedok, menuju arah jembatan. Kepergian Jenderal Soedirman dari Dukuh Sobo masih dirahasiakan karena daerah Pacitan belum ada gencatan senjata. 
Rombongan sewaktu-waktu masih dapat diserang Belanda.

Dari Sobo perjalanan menuju Penggung, Nawangan dan Ambarsari, Tirtomoyo dan sampai di Pracimantoro (wawancara dengan Joko Mulyono, tanggal 11 April 2011).

\section{Kesadaran Sejarah dan Partisipasi Masyarakat}

Menurut Saimen (wawancara tanggal 11 April 2011) pembangunan monumen Jenderal Soedirman sangat berarti sebagai bentuk mengenang jasa-jasa Jenderal Soedirman. Disamping itu juga sebagai tempat pariwisata sehingga akan membawa dampak positif bagi masyarakat Desa Pakis Baru tersebut terutama dapat meningkatkan perekonomian masyarakat sekitar monumen Jenderal Soedirman. Beliau juga menjelaskan sebagai warga masyarakat Desa Pakis Baru berkewajiban untuk melestarikan monumen Jenderal Soedirman tersebut yaitu dengan menjaga dari pihak-pihak yang tidak bertanggung jawab.

Menurut Sunaryanto (wawancara tanggal 21 April 2011) menjelaskan bahwa partisipasi masyarakat pada saat ini sangat kurang, hal ini dilihat dari perbandingan partisipasi masyarakat pada jaman dahulu dan sekarang sangat jauh berbeda. Pada jaman dahulu masyarakat masih sering mengadakan semacam bakti sosial atau keja bakti guna menjaga kebersihan dan keindahan monumen Jenderal Soedirman tetapi pada jaman sekarang masyarakat justru enggan karena mereka menganggap bahwa untuk menjaga kebersihan dan keindahan monumen sudah menjadi tanggung jawab petugas monumen.

Joko Mulyono (wawancara tanggal 13 April 2011) menjelaskan bahwa monumen Jenderal Soedirman adalah salah satu bangunaan yang mempunyai nilai sejarah yang sanggat penting yaitu untuk mengenang jasa Jenderal Soedirman saat berjuang melawan Belanda. Sebagai generasi penerus wajib menjaga kelestariaan monumen Jenderal Soedirman tersebut. Beliau menjelaskan bahwa partisipasi masyarakat pada saat ini mulai berkurang, hal ini dapat dilihat dari upaya penjagaan kebersihan dan keindahan lokasi monumen Jenderal Soedirman, jika tidak ada himbauan dari pemerintah desa mengenai bakti sosial, hal ini belum ada kesadaran dari masyarakat sendiri, mereka cenderung memyerahkan kepada orang yang memang diperkerjakan di monumen tersebut karena mereka yang telah di bayar dan bertanggung jawab dalam pembangunan maupun menjaga monumen tersebut.

Sidik (wawancara tanggal 11 April 2011) menjelaskan bahwa beliau merasa sangat bertanggung jawab terhadap keberadaan monumen Jenderal Soedirman, sebelum beliau menjadi petugas monumen Jenderal Soedirman beliau dengan ikhlas selalu menjaga dan membersihkan lokasi monumen tersebut, karena beliau beranggapan bahwa monumen Jenderal Soedirman adalah bangunan yang sangat berharga dan beliau bangga karena di tempat tersebut telah dibangun salah satu bangunan yang sangat bersejarah. Oleh karena ketelatenannya tersebut oleh pemerintah beliau dipercaya dan ditugasi sebagai penjaga monumen sampai sekarang.

Soeroso (wawancara tanggal $11 \mathrm{Mei}$ 2011) menjelaskan keberadaan monumen Jenderal Soedirman sangat besar manfaatnya selain sebagai bentuk untuk menghargai jasa-jasa pahlawan kita, juga sangat bermanfaat khususnya bagi dunia pendidikan. Monumen Jenderal Soedirman sebagai salah satu peninggalan sejarah dapat dijadikan sebagai media pembelajaran khususnya pendidikan sejarah, sehingga 
para siswa dapat mengetahui riwayat hidup pahlawan, jasa-jasa pahlawan dalam berjuang demi mencapai kemerdekaan dan juga untuk menumbuhkan sikap nasioalisme pada siswa.

\section{Pembahasan}

Sebagai warga Negara Indonesia dan sebagai manusia, mau tidak mau setiap orang terlibat dan ikut bertanggung jawab baik di dalam pembuatan sejarah maupun di dalam penulisan sejarah bangsanya, karena suatu bangsa menghadapkan diri dengan kenyataan, dengan realitas sosial dalam perspektif hari kini, hari lampau dan perspektif hari depan. Penting bagi suatu bangsa untuk memperdalam dan mempertegas pengertian sejarahnya yang dapat menyinari dan memghayati kepribadian nasional. Refleksi diri yang kontinu berdasarkan kesadaran sejarah akan membebaskan manusia Indonesia dari rasa diri yang serba metologis. Kesadaran sejarah merupakan orientasi intelektual, suatu sikap jiwa yang perlu untuk memahami secara tepat paham kepribadian nasional (Soedjatmoko, 1986:66-67).

Keberadaan monumen Jenderal Soedirman sejak tahun 1998 telah mengalami perubahaan-perubahan yaitu sejak pemerintah daerah mengajukan proposal kepada pemerintah pusat guna perehabilitasian bangunan monumen yang keberadaannya terbengkalai. Monumen Jenderal Soedirman awalnya ini dibangun oleh lurah Pakis yang bernama Roto Soewarno, beliau adalah kurir Jenderal Soedirman ketika tnggal di Dukuh Sobo Desa Pakis Baru. Awalnya monumen Jenderal Soedirman hanya terdiri dari patung dan halaman yang tidak begitu luas, namun sekarang setelah dikelola oleh pemerintah keberadaan berkembang yaitu dengan dibangunnya sarana-sarana lain diantaranya lapangan pendaratan helikopter, ruang resepsionis, ruang diorama, perpustakaan, restoran, gedung teater, pasar seni, kamar mandi umum serta penginapan serta lapangan perkemahan yang cukup luas. Monumen Jenderal Soedirman merupakan peninggalan sejarah yang mempunyai nilai historis yang tinggi, oleh karena itu perlu dibutuhkan sikap kesadaran sejarah dari masyarakat guna menjaga kelestariannya.

Peninggalan sejarah dapat dijadikan sebagai sarana pendidikan khususnya kepada generasi penerus guna menambah wawasan kesejarahan sehingga akan menimbulkan pengetahuan dan sikap menghargai terhadap peninggalan-peninggalan sejarah. Namun keberadaan monunen Jenderal Soedirman ini kurang diminati oleh masyarakat. Adapun pengunjung monumen Jenderal Soedirman ini pada hari-hari biasa sangat sedikit, rata-rata hanya anak pelajar. Pengunjung mengalami peningkatan hanya pada hari libur. Masyarakat Desa Pakis Baru khususnya dan masyarakat Indonesia pada umumnya seharusnya lebih dapat menghargai dan melestarikan monumen Jenderal Soedirman karena keberadaan monumen Jenderal Soedirman patut dibanggakan karena merupakan peninggalan sejarah yang sangat berharga dan mempunyai nilai historis yang sangat tinggi.

Namun dari hasil penelitian yang telah dilakukan menunjukkan bahwa kesadaran sejarah dan partisipasi masyarakat terhadap pelestarian monumen Jenderal Soedirman yang terletak di Dusun Sobo Desa Pakis Baru masih sangat kurang hal ini disebabkan oleh beberapa hal yaitu:

a) Kurangnya kesadaran masyarakat tentang arti pentingnya peninggalan sejarah.

b) Masyarakat yang bersifat materialistis.

c) Masyarakatnya cenderung menunggu perintah desa. 
d) Kurangnya sosialisasi tentang pentingnya peninggalan sejarah.

Untuk itu perlu dilakukan upaya untuk membangkitkan kesadaran masyarakat guna melestarikan keberadaan monumen Jenderal Soedirman. Adapun upaya tersebut diantaranya:

a) Diadakan

penyuluhan-penyuluhan mengenai pentingnya menjaga dan merawat peninggalan sejarah.

b) Mensosialisasikan keberadaan monumen Jenderal Soedirman sebagai aset yang sangat berharga dan bernilai tinggi sehingga akan menumbuhkan kesadaran masyarakat untuk berpartisipasi dalam upaya pelestarian monumen, dan menumbuhkan kebiasaan-kebiasaan gotong royong yaitu dengan diadakan bakti sosial secara rutin dalam pemeliharaan monumen, sehingga masyarakat tidak cenderung materialistis.

c) Menghilangkan kebiasaan masyarakat yang cenderung menunggu perintah dari desa.

d) Mengadakan sosialisasi kepada masyarakat mengenai pentingnya peninggalan sejarah bagi kita dan generasi penerus sehingga perlu dijaga kelestariannya.

Berkaitan dengan hal tersebut dapat dilihat bahwa kesadaran sejarah masyarakat Desa Pakis Baru terhadap monumen Jenderal Soedirman masih sangat rendah hal ini dapat diketahui dari kesadaran sejarah dan partisipasi warga Desa Pakis Baru. Hal ini dikarenakan mereka menganggap sudah ada petugas monumen yang bertanggung jawab terhadap keindahan dan kebersihan monumen. Masyarakat akan turut serta berpartisipasi apabila ada himbauan dari pemerintah desa. Selain itu juga dipengaruhi oleh tingkat pendidikan masyarakat yang mayoritas tamatan SD yaitu mencapai $49,44 \%$, sedangkan yang tidak tamat sekolah mencapai 2,89\%, karena dipengaruhi oleh tingkat pendidikan yang masih rendah maka sebagian masyarakat Desa Pakis Baru kurang mempunyai kesadaran terhadap peninggalan sejarah tersebut yang merupakan aset penting bagi generasi mendatang sehingga sangat perlu dijaga kelestariannya.

Apabila monumen Jenderal Soedirman dapat terawat dengan baik maka akan berkembang menjadi tempat pariwisata sejarah, sehingga hal ini akan sangat menguntungkan khususnya bagi masyarakat karena akan meninggkatkan ekonomi masyarakat sekitar monumen Jenderal Soedirman.

\section{Simpulan dan Saran}

\section{Simpulan}

Kesadaran sejarah dan partisipasi masyaraka Desa Pakis Baru dalam pelestarian monumen Jenderal Soedirman masih sangat kurang. Hal ini disebabkan oleh beberapa hal diantaranya tingkat pendidikan penduduk Desa Pakis Baru yang sebagian besar masih tamatan Sekolah Dasar (SD) yang mencapai $49,44 \%$ sedangkan yang tidak tamat sekolah mencapai 2,89\%. Hal ini menyebabkan pengetahuan dan kesadaran sejarah masyarakat mejadi kurang. Keadaan Masyarakatnya yang bersifat materialistis dan cenderung menunggu perintah dari aparat desa. Kurangnya sosialisasi tentang pentingnya peninggalan sejarah.

Kondisi di atas merupakan gambaran nyata bahwa partisipasi masyarakat terhadap keberadaan monumen Jenderal Soedirman benar-benar masih kurang. Peninggalan sejarah merupakan bukti sejarah bangsa yang semestinya harus dilestarikan serta ditanamkan bagi generasi penerus agar mempunyai kesadaran dan sikap menghargai terhadap peninggalan sejarah. 


\section{Saran}

a. Meningkatkan pendidikan masyarakat baik formal maupun non formal.

b. Mengadakan sosialisasi kepada masyarakat, di sekolah dan intansi pemerintahan untuk menanamkan nilai budaya dan kesadaran sejarah.

c. Meningkatkan kesadaran masyarakat dengan jalan mengadakan bakti sosial secara rutin untuk menjaga kebersihan dan keindahan monumen.

d. Meningkatkan pemeliharaannya sehingga dapat mencerminkan identitas masyarakat setempat. 
36|Agastya Vol. 02 No. 01 . Januari 2012

\section{Daftar Pustaka}

Depdikbud. 1986. Pemikiran Tentang Pembinaan Kesadaran Sejarah. Jakarta

Basrowi dan Suwandi. 2008. Memahami Penelitian Kualitatif. Jakarta: Rineka Cipta

I Gde Widja. 2002. Menuju Wajah Baru Pendidikan Sejarah. Yogyakarta: Lappera Pustaka utama

Khairuddin. 2000. Pembangunan Masyarakat Tinjauan Aspek Sosiologi, Ekonomi dan Perencanaan. Yogyakarta: Liberti

Mikkelesen, Brita dan Matheos Nale (Ed). 2003. Metode Penelitian Partisipatoris dan Upaya-Upaya Pemberdayaan. Jakarta: Yayasan Obor Indonesia

Moh Soerjani. 1987. Lingkungan Sumber Daya Alam dan Kependudukan dalam Pembangunan. Jakarta: Universitas Indonesia

Rustam E Tamburaka. 1999. Pengantar IImu Sejarah, Teori Filsafat dan Iptek. Jakarta: Rineka Cipta

Soedjatmoko. 1986. Dimensi Manusia dalam Pembangunan. Jakarta: LP3ESTjokropranolo. 1992. Panglima Besar Jenderal Soedirman Pemimpin Pendobrak Terakhir Penjajahan Di Indonesia. JakartaS: urya Persindo

http://wikipedia.org/wiki/Soedirman, diakses 15 Januari 2011. 